\title{
Промышленность по добыче и обработке полезных ископаемых КМА в ЦЧО в 1930-е годы: проблемы и трудности развития. Часть 3
}

\author{
Прокофьева Е.Ю. \\ Белгородский государственный национальный исследовательский университет, \\ 308015. г. Белгород, ул. Победы, 85 \\ E-mail: prokofievaeu@mail.ru
}

\begin{abstract}
Аннотация. В статье анализируются трудности процесса преодоления сложившихся стереотипов, состоявших в том, что Центральное Черноземье не должно подпадать под планы форсированного индустриального переустройства хозяйства $\mathrm{c}$ приоритетом развития предприятий тяжелой промышленности группы «А», но сохранять сложившуюся аграрную специализацию. Автор в ходе анализа трудностей, имевших место при переходе страны к административно-командным методам руководства в годы предвоенных пятилеток, отмечает, что администрирование в регионе усилилось и приобрело жесткий директивный характер при запуске широкомасштабного процесса разведки и начала промышленного освоения железорудных богатств КМА. Введение в научный оборот репрезентативного архивного материала позволило автору выявить существенные противоречия, имевшие место в оценках плановых возможностей развития КМА между центральными и местными органами власти, что в конечном итоге вело к завышению показателей плановых заданий и недостоверным сведениям, предоставляемым в отчетах руководством региона в Москву.
\end{abstract}

Ключевые слова: Центрально-Черноземная область (ЦЧО), Курская магнитная аномалия (КМА), Комиссия Исполнения (КИ), Рабоче-Крестьянская Инспекция (РКИ), Районное государственное геологическое техническое управление (РайГГТУ), Районный исполнительный комитет (советов) (РИК), Высший совет народного хозяйства (BCHX), лишенные гражданских избирательных прав (лишенцы).

Для цитирования: Прокофьева Е.Ю. 2021. Промышленность по добыче и обработке полезных ископаемых КМА в ЦЧО в 1930-е годы: проблемы и трудности развития. Часть 3. Via in tempore. История. Политология, 48 (2): 445-456. DOI: 10.52575/2687-0967-2021-48-2-445-456.

\section{Mining operations industry of KMA on the territory of Central Black Earth Region in 1930-s: problems and difficulties of development. Part 3}

\author{
Elena Yu. Prokofieva \\ Belgorod National Research University, \\ 85 Pobeda St., Belgorod, 308015, Russia \\ E-mail: prokofievaeu@mail.ru
}

\begin{abstract}
It is the third conclusive article of the history of extraction and processing Kursk magnetic anomaly industry in 1920-1930-s. Difficulties of pattern overcoming that took place in expert circles and also in party lidership of the Central Black Earth region are analyzed by the author; the main stereotype was to save the agricultural focus of the Black Earth region and to develop heavy industry i.e. mining, electro-technical and chemical industry of A group as the main priority of economy at the same time. Debates about the main points of industry development that took place during 1920-s and also the lack of qualified personnel and finance retarded the processing and large scale mineral exploration and industrial exploration of the Kursk magnetic anomaly so that it really began only in 1930-s. Usage of the


representative archive material of the special economical journals of designated period allows the author to show significant controversies in the estimates and overestimation of unreliable planned aims of the Kursk magnetic anomaly development that were transferred from the regions to Moscow.

Key words: The Central Black Earth Region, Kursk magnetic anomaly, Comession run, Workers and Peasants' Inspection, Regional State Geological Technical Management, Regional Execitive Committee, Upper Council of national Economy, deprived of civil rights.

For citation: Prokofieva E.Yu. 2021. Mining operations industry of KMA on the territory of Central Black Earth Region in 1930-s: problems and difficulties of development. Part 3. Via in tempore. History and political science, 48 (2): 445-456 (in Russian). DOI: 10.52575/2687-0967-2021-48-2-445-456.

\section{Введение}

Актуальность данной темы обусловлена сегодня объективно поставленными перед Российской Федерацией задачами реализации в стране нового витка индустриальной модернизации, в рамках которого необходимо добиться возможности работы национальной экономики на базе максимально возможного импортозамещения. В этой связи исторические уроки достижений и ошибок, имевшие место в ходе широкомасштабного процесса освоения природных богатств Курской магнитной аномалии на территории ЦЧО в ходе развертывания социалистической индустриализации в СССР, главные цели которой практически совпадали с современными задачами, стоящими перед нашей страной, представляют не только научно-теоретический, но и вполне прикладной интерес для обеспечения государственной безопасности России.

Вместе с тем, несмотря на то что в начале 1960-х годов были изданы несколько томов документального материала по истории освоения КМА [Курская магнитная аномалия, 1961], исторических научных публикаций по проблеме до сих пор крайне мало. И, как правило, это диссертационные исследования 1960-х годов и более позднего времени [Кривошеев, 1965; Юров, 1967; Мальцев, 1968; Слободенюк, 2009; Толмачева, 2011]. При этом в них отсутствует постановка задачи раскрыть ошибки, проблемы, трудности и недочеты в ходе развертывания процесса освоения КМА в 1930-е годы.

Новизна исследования заключается в том, что научные исторические публикации, посвященные освоению и развитию КМА в XX веке, хронологически начинаются, как правило, с послевоенного времени, не затрагивая «проблемных» 1930-х годов [Антропов, 1958; Шевяков, Маньковский, 1962; Бусыгин, 1969; Крупенков, 1973; КМА набирает..., 1974; Железорудная база..., 1998; Быковская, 2000].

Исключением стала содержательная научная статья О.В. Пешехоновой [Пешехонова, 2011]. Но и в ней автор не ставила задачу анализа ошибок и трудностей, имевших место в обозначенный период освоения КМА, ограничившись освещением в хронологической последовательности самого процесса развертывания строительства добывающих и перерабатывающих предприятий КМА.

Для данной публикации представляют особую значимость документы, извлеченные автором из фонда Р-1439 (Центрально-Черноземный Исполнительный Комитет Совета рабочих, крестьянских и красноармейских депутатов за 1928-1934 гг.) государственного архива Воронежской области (ГАВО), которые впервые вводятся в научный оборот. Это, прежде всего, материалы, содержащиеся в описи 4, в делах № 229, 230 и 231; в них в числе прочих представлены постановления Президиума Облисполкома ЦЧО и Комиссии Исполнения при Облисполкоме ЦЧО от 26 августа 1931 г. «О выполнении постановления Обкома ВКП(б) ЦЧО от 27 апреля 1931 г. о ходе реконструкции и строительства Липецких заводов, рудников и строительстве новых шахт»; «О ходе разведочных работ и строительстве КМА»; «О результатах проверки выполнения постановления Комиссии Исполнения от 6 октября 1931 г. по вопросу предоставления квартир инженерно-техническим работникам КМА»; постановления Президиума Облисполкома ЦЧО «О ходе индустриали- 
зации в ЦЧО» (1931 г.) и «О развитии отраслей промышленности ЦЧО в 1928-1934 гг.»; доклады председателя Старооскольского горисполкома Косарева «О трудностях и недостатках в ходе предоставления квартир работникам КМА» и информация Комиссии Исполнения о фактическом невыполнении ее постановления «О снабжении КМА». Кроме того, в данной описи представлены документы о контрольных цифрах планов по развитию промышленности ЦЧО на 1932-1935 гг.

\section{Объект и методы исследования}

Объектом статьи явились проблемы и трудности развития промышленности по добыче и обработке полезных ископаемых Курской магнитной аномалии на территории ЦЧО в 1930-е годы. В основу при написании статьи легли принципы научности, объективности и историзма. Они позволили определить основные направления развития ЦентральноЧерноземного региона в условиях перехода СССР к пятилетнему планированию на среднесрочную перспективу, выявить особенности складывания народнохозяйственного комплекса в ЦЧО на базе постановки таких нетрадиционных ранее для Черноземья задач, как индустриализация. Для выявления трудностей при подведении новой технической и технологической базы под широкомасштабную разработку и промышленное освоение железорудных месторождений КМА были применены сравнительно-исторический, проблемнохронологический и логический методы. По мнению автора, это позволило дать объективную оценку спорам о целесообразности избрания курса на индустриальное развитие традиционно аграрного региона, продолжавшимся вплоть до конца 1920-х годов, и с большей достоверностью реконструировать особенности и имевшие место ошибки при постановке приоритетных задач в планах развертывания полномасштабного освоения КМА в первой половине 1930-х годов.

\section{Результаты и их обсуждение}

С учетом изложенного в первой и второй частях ранее проведенного автором данной статьи исследования заявленной проблемы, раскрывающего сущность и масштаб многочисленных трудностей, имевших место при постановке задач восстановления и планов по развертыванию процесса перевода на индустриальные рельсы добывающих отраслей промышленности в таком традиционно аграрном регионе, как Центральное Черноземье [Прокофьева, 2015, с. 162-167; Прокофьева, 2016, с. 150-156], к началу 1930-х годов вполне закономерным результатом стал ряд постановлений особой Комиссии Исполнения (КИ), созданной при Облисполкоме ЦЧО. В первом постановлении КИ от 6 июля 1931 г. анализировалось выполнение постановления обкома ВКП(б) ЦЧО от 12 мая и облисполкома ЦЧО от 5 апреля 1931 г. «О реконструкции Липецких рудников и строительстве новых шахт». В документе отмечалось следующее: «Заслушав доклад управляющего Сырских рудников т. Каплунова... о реконструкции рудников и строительстве новых шахт и содоклад представителя ОблРКИ т. Васильева, Комиссия установила, что... подготовительные работы по проходке новых шахт и развертыванию строительства гражданских и технических сооружений, запроектированных на 1931 г., осуществляются такими темпами, которые ни в какой мере не могут обеспечить добычу руды в нужном количестве для пуска новых доменных печей к установленному сроку - 1 июня 1932 г.» ${ }^{31}$. Далее в докладе констатировалось значительное недовыполнение плановых заданий: «Из утвержденного окончательно правлением «Сталь» к постройке на 1931 год 11 новых шахт на 1 июля текущего года находится в проходке 9 шахт, из них по 2-м шахтам проходка ствола отложена и по 3-м - стволы пройдены..., что составляет 56 \% выполнения по метражу; к демонтажу Гданцевской эл./ст. (1500 квт) лишь приступили; ...изыскательные работы по

${ }^{31}$ Государственный архив Воронежской области (ГАВО). Ф. Р-1439. Оп. 4. Д. 229. Л. 1, 4. 447 
постройке подъездных ж/д путей к шахтам и карьерам только заканчиваются; ...установлена в шахте № 3 только одна электролебедка...» ${ }^{32}$.

Поскольку КИ являлась, по сути, структурой партийных и советских руководящих органов ЦЧО, в отличие от хозяйственников, специалистов-практиков и ученых, признать планы геологоразведок и ввода в эксплуатацию объектов «необоснованно завышенными» она не могла, так как в этом случае руководству региона нужно было бы «отвечать» за срыв плановых показателей перед вышестоящим начальством в Москве. Поэтому в постановлении КИ вместо объективной оценки необоснованного завышения показателей при составлении плана развития отрасли были найдены «виновные» в срыве выполнения непосильных заданий. Ими оказались «тов. Бобков и Журбенко (ЦЧстрой), Белинин и Шапиро (Леспромтрест), Фаерман и Баум (Облснаб), Челышев (Союзхлеб), Калинин и Гудков (Союзпромкорм), Паринов и Молешкин (Облотдел труда), Шабанов, Непрокин и Терентьев (Облдортранс), Светличный и Холченко (Липецкий горсовет), которые не выполнили постановления Обкома от 12 мая и Облисполкома от 5 апреля, чем не создали нормальных условий для строительства новых шахт» ${ }^{33}$.

Во втором постановлении КИ от 26 августа 1931 г. о ходе Липецких разведок Комиссия Исполнения ...устанавливает: постановление Обкома ВКП(б) от 27 апреля 1931 г. полностью не реализованы организациями, ведающими Липецкими рудными разведками, результатом чего темпы разведок продолжают оставаться недостаточными; происходит распыление геолого-разведочных работ...; разведочные работы на хозрасчет не переведены...; прогрессивно-сдельная оплата труда не введена; буровые работы на 3-х сменную работу не переведены; наличное оборудование полностью не используется; общее и техническое руководство в надлежащей мере не осуществляется; рационализаторская работа, соцсоревнование и ударничество не развернуты; к закреплению рабочей силы на разведках мер не принято; снабжение продовольствием и промтоварами недостаточно; финансирование разведок проходит с опозданием» ${ }^{34}$.

В итоговом постановлении КИ в лучших традициях административно-командной системы управления предписывалось: «Работу по разведкам перестроить, концентрировав разведки в массивах наибольшего залегания рудных месторождений, наметив в декадный срок конкретные меры для выполнения плана проходки и провести их в жизнь» ${ }^{35}$.

В еще одном докладе «О КМА» от 6 октября 1931 г. Комиссия Исполнения констатировала, что ни по одному пункту указанных в августе 1931 г. недостатков существенного улучшения к октябрю месяцу не произошло. В докладе сообщалось, что, во-первых, крайне неудовлетворительно обстояло дело с материально-техническим снабжением КМА спецоборудованием и стройматериалами. «По п. 1 - «Обеспечение норм проходки... и выполнение промфинплана» ... задерживалось непоставками оборудования. В октябре месяце на IV квартал не присланы запасные станки... с буровым оборудованием; обсадные трубы 112, 127 и 73 мм; колонковые трубы 129, 114, 99, 84, 54 и 44 мм; переходники... и другое оборудование. Снабжение истирающими материалами проходит также неудовлетворительно... В связи с несвоевременной отгрузкой оборудования Геолснабом... ликвидация аварий задерживается... Винторезный станок, фрезерный станок и механический молот... до сего времени не получены. Оборудование для чеканочной мастерской не получено... По снабжению ЦЧСнаб задерживает выполнение и реализацию заявок КМА... По п. 2 - «Выполнение всех нарядов на стройматериалы, скобяные, москательные и селикатные изделия» ЦЧСнабом почти не выполняется... Наряды на сентябрь и октябрь месяцы сего года на 2500 кубометров лесоматериалов выполнен только на $40 \%$... При отсутствии пиломатериалов и лесоматериалов работа по постройке 20 новых вышек для пребы-

\footnotetext{
32 Там же. Л. 2.

${ }^{33}$ Там же. Л. 3.

${ }^{34}$ ГАВО. Ф. Р-1439. Оп. 4. Д. 230. Л. 1.

35 Там же.
} 
вающих новых буровых станков будет сорвана, получатся простои станков и срыв выполнения производственного плана. Только 13. ХІ. 31 г. ОблСНХ уведомил, что... Базе КМА предоставлена рамочная лесопильная пила с Буторлиновского завода, но она неисправна и требует ремонта» ${ }^{36}$. Имелись серьезные претензии и к снабжению вспомогательных мастерских, переданных в состав КМА, к отставанию в графиках строительства дорожного сообщения, телефонной связи и пр. В постановлении КИ также отмечалось, что «снабжение поделочными материалами мастерских, входящих в объединение КМА, Геолснабом проводится неудовлетворительно... Строительство дороги КМА от г. Старого Оскола до Салтыково в срок... не окончено ввиду невыполнения трудгужповинности Старооскольским и Скороднянским РИКами, хотя по постановлению Старооскольского РИКа сельсоветы района обязаны были выполнить норму вывозки 16276 куб. метров песка, но выполнили только 3056 куб. метров; а Скороднянский РИК порученное задание выполнил только на 1,9 \% ... По улучшению телефонной связи между КМА и Салтыково, где велись буровые работы, Облконторой никаких мер не было принято... Наряд от ОблСНХ на 360000 шт. кирпича и также на 10 вагонов извести получен своевременно, но перевозка их не произведена, т. к. Союзтранс, несмотря на заключенный с ними договор, категорически отказывается от перевозки этих грузов, ссылаясь на бездорожье... Положение с доставлением вагонов под грузы КМА неудовлетворительное» ${ }^{37}$.

КИ отмечала и плохое снабжение сотрудников необходимой спецодеждой. Проверка выявила, что «до сего времени База КМА своевременно и полностью спецодеждой не удовлетворена: снабжение сапогами осуществлено на $32 \%, \ldots$ кожаными костюмами на $10 \%$, холщевыми фартуками - на $79 \%$, ботинками - на 4,6\%, халатами - на 24,9\%, ватными шароварами - на $41 \%$, овчинными куртками - на 55,6 \%, нательным бельем - на 11,4 \%». КИ констатировала и невыполнение предписаний областных властей целевым назначением направлять для работников КМА «дефицитные товары», в основном одежду по сниженной, т. н. «городской» цене. В докладе КИ, в частности, сообщалось, что «поступление дефицитных товаров на Базу КМА и снабжение сотрудников идет почти целиком по (более высоким - Е.П.) ценам сельского сектора, и преимущественно детским ассортиментом» $^{38}$.

Далеко не лучшим образом обстояло дело и с продовольственным и топливным снабжением КМА, а также с обеспечением рабочих мылом. Проверка показала, что «снабжение мясом идет с перебоями. Снабжение мылом идет с большими перебоями... В отношении снабжения иждивенцев Облснаб и Облпотребсоюз до сего времени не договорились, таким образом, иждивенцы KMA в IV квартале не снабжаются... В топливе для столовых и хлебопекарен Энергобюро отказало, вследствие чего грозит срывом... снабжения рабочих хлебом и питанием. В наряде на фураж 12 лошадей, занятых по доставке продуктов питания из г. Старый Оскол до с. Салтыково, Облснабом отказано. Отмечается халатное отношение работников Облпотребсоюза к отправке товаров, в частности, незнание точного адреса нахождения Базы КМА. Имели место случаи засылки товаров, принадлежащих Базе КМА, в г. Курск, что создавало излишнюю переписку и задержку реализации товаров» ${ }^{39}$.

Вывод повторной проверки Комиссией Исполнения состояния дел, сформулированный помощником ответственного исполнителя КИ Анпиловым, был неутешителен: «Из всего перечисленного видно, что снабжение КМА даже после постановления Комиссии Исполнения ничуть не улучшилось, ... что отразится на выполнении производственного плана и получится текучесть в рабсиле... Суммируя все данные о выполнении поста-

\footnotetext{
${ }^{36}$ Там же. Д. 231. Л. 38-38 об., 39 об.

37 Там же. Л. 38-38 об., 39 об., 40-40 об.

38 ГАВО. Ф. Р-1439. ОП. 4. Д. 231. Л. 38, 39.

${ }^{39}$ Там же. Л. 39.
} 
новления Комиссии Исполнения... явствует, что решения руководящих органов о работе КМА все же остаются невыполненными...» ${ }^{40}$.

Осенью и зимой 1931-1932 г. КИ продолжила свою работу, отметив, что в числе нерешенных наиболее болезненным являлся «квартирный вопрос», то есть проблема обеспечения инженерно-технического и рабочего персонала КМА жильем. Ситуация с жильем была крайне сложная. Еще в 1928/29 хозяйственном году руководство КМА сообщало в Облисполком и Обком ЦЧО: «Заслуживает особого внимания текучесть рабочей силы вообще и в особенности на Сырских рудниках. За 1928/29 г. принято было рабочих 3816 чел., и уволились - 3179 чел., то есть из числа принятых остались на работе лишь 637 чел. ... Бытовые условия ...ддовольно тяжелы и в значительной степени влияют как на состав кадров по качеству, так и по текучести. На рудниках повсеместно ощущается отсутствие или антисанитарное состояние жилых помещений. Рабочие живут в землянках...» ${ }^{41}$.

В первой половине 1930-х годов положение с жильем на КМА существенных изменений не претерпело. В очередном докладе зампредседателя КИ Цветкова о результатах проверки выполнения постановления Облисполкома ЦЧО от 6 октября 1931 г. «По вопросу предоставления квартир инженерно-техническим работникам КМА» говорилось следующее: «Необеспеченность квартирами вызывает текучесть работников. Горкоммунхоз удовлетворил квартирами сотрудников КМА на $38 \%$; 18 \% квартир подыскано самой Базой КМА и $44 \%$ сотрудников квартирами не удовлетворены. Возвратившиеся с полевых работ сотрудники полевых партий не имеют квартир» ${ }^{42}$.

К зиме 1932 г., как следует из документов, положение оставалось не менее сложным. «За время с 1 марта 1931 г. по 1 февраля 1932 г. Старооскольским горсоветом было предоставлено для инж.-технич. работников (ИТР) КМА 23 отдельных квартиры и 12 квартир в двух домах, ремонт которых произведен силами и средствами КМА... В настоящее время 15 человек... находятся в течение 2-х месяцев без квартир... За декабрь-январь месяцы в связи с непредоставлением квартир ушли с работы 4 инженера. От одного инженера, находящегося в отпуску, получено письмо, в котором он пишет, что если ему не будет предоставлена квартира до 10 февраля текущего года, то он на работу не приедет... Директором КМА т. Павловским дана заявка в Москву об откомандировании 9 инженеров, 12 геологов, 5 техников, 7 прорабов, 9 топографов, 7 физиков и т. д., а всего 50 человек, для которых квартир в Старом Осколе нет. Вину (за это - Е.П.) председатель Старооскольского горсовета Завьялов возложил на директора Базы КМА Павловского, который якобы не отремонтировал 2-этажный дом на 20 квартир, переданный горсоветом КМА по договору от 26 августа 1931 г. Завьялов заявил, что при передаче дома горсовет дал стройматериалов на сумму 8294 руб., однако Павловский не стал ремонтировать дом, а надстроил 3-й этаж. По сообщениям Завьялова, жилищный кризис в Старом Осколе углубился и потому, что в Старый Оскол были переведены совпартшкола и техникум...» 43 .

Обвинения председателя Старооскольского горисполкома Завьялова в адрес директора Базы КМА Павловского КИ сочла неубедительными. Более того, по ее решению сам Завьялов был снят с занимаемой должности по весьма своеобразной причине - «за то, что не принял никаких мер к выселению в летний период лишенцев в пригородные села с целью предоставления этих квартир работникам КМА, что в значительной степени удовлетворило бы работников КМА квартирами» ${ }^{44}$.

\footnotetext{
${ }^{40}$ Там же. Л. 39, 41.

${ }^{41}$ Государственный архив общественно-политической истории Воронежской области (ГАОПИВО). Ф. 2. Оп. 1. Д. 1204. Л. 28.

${ }_{42}$ ГАВО. Ф. Р-1439. Оп. 4. Д. 231. Л. 40 об.

${ }^{43}$ Там же. Л. $1-1$ об.

${ }^{44}$ Там же. Л. 1 об.
} 
Однако увольнение советского чиновника, принудительно не выселившего лишенных (по политическим и экономическим соображениям) избирательных прав горожан в сельскую местность, ситуацию существенно не улучшило. Вновь назначенный председатель горисполкома Старого Оскола Косарев в своем докладе Комиссии Исполнения попытался объяснить причины сложившейся ситуации с «жилищным кризисом» в городе. Однако в представленных аргументах он вынужден был фактически повторять слова своего снятого с должности предшественника: «Жилая площадь города определяется (к зиме 1932 г. - Е.П.) в 34959 кв. метров при наличии населения города 8700 чел, что составляет в среднем на 1 душу 4 кв. метра жилой площади... Кроме того, в 1931 г. в Старый Оскол переведены: Совпартшкола, Зерновой и Ветеринарный рабфаки, Межрайонная Коопшкола. Вновь организованы Стройуч, пед. курсы и межрайонные непрерывные курсы советского строительства... и вновь расквартирована Военная часть РККА... Расширены: на 2 группы с/х техникум и на 2 группы пед. техникум...» 45 .

Таким образом, несмотря на все усилия администрации, острота жилищного вопроса в Старом Осколе в начале 1930-х гг. не только не снижалась, но с развертыванием КМА приобретала социально конфликтный характер, что вынужденно отразилось в официальных документах того времени. Так, все объяснения Косарева не были приняты в расчет, и в докладе Комиссии Исполнения сообщалось, что «новый председатель горсовета т. Косарев до сих пор не предоставил в распоряжение КМА квартиру взамен отобранной и переданной им помощнику начальника милиции, в которой раньше жил работник КМА т. Абрамов» ${ }^{46}$. В результате в своих выводах, сформулированных инспектором Кустовым, КИ «для исправления ситуации» предписывала: «предложить председателю СтароОскольского горсовета провести соответствующие уплотнения квартир с предоставлением уплотненной жилплощади под квартиры ИТР Базы КМА; поставить вопрос перед Облпрокурором о разрешении выселения в зимний период лишенцев в пригородные села и предоставления этих квартир ИТР КМА; обязать т. Павловского обеспечить полное окончание капитального ремонта 2-этажного дома не позже 1 июня текущего года; обязать председателя горсовета в 2-декадный срок предоставить квартиру в распоряжение КМА взамен отобранной квартиры, в которой жил сотрудник КМА т. Абрамов» (выделено - Е.П.) ${ }^{47}$.

Несмотря на жесткую критику крайне неблагополучной ситуации по выполнению утвержденных плановых заданий, связанных с разведкой и освоением КМА и реконструкцией Липецких рудников, звучавшую в докладах Комиссии Исполнения в Воронеже, по поручению партийно-советского руководства ЦЧО эта же Комиссия отправляла в Москву и в центральные органы крупных хозяйственных объединений вполне бодрые отчеты, в которых фактически искажалось истинное положение дел. В качестве примера возможно привести выдержки из целого ряда таких сообщений, отправленных КИ в сентябре 1931 г. в Москву в ВСНХ СССР, и в Харьков, где находились головные конторы крупного производственного объединения «Сталь» и горнодобывающего треста «Руда». «Металлический сектор ВСНХ СССР своим письмом от 13 августа 1931 г. за № 03316 препроводил нам постановление Комиссии Исполнения при ЦЧ Облисполкоме от 6 июля с. г. «О реконструкции Липецких рудников». В соответствии с постановлением правительства об обязательном окончании работ по постройке Липецкого госметзавода в июне месяце 1932 г., «Рудой» были развернуты работы для обеспечения окончания строительства новых Липецких рудников на месяц раньше (плана - Е.П.), т. е. к маю месяцу 1932 г. Окончательный проект развития рудничного хозяйства с добычей в 2 млн тонн сырой руды принят от Гипромеда в начале июля с. г., согласно проекту, утвержденногому «Сталью». Эта добыча обеспечивается 6 шахтами (5 (шахт - Е.П.) - по 300 тыс. и 1 (шахтой - Е.П.) - в 500 тыс.

\footnotetext{
${ }^{45}$ Там же. Л. 8-10.

46 Там же. Л. 1.

${ }^{47}$ ГАВО. Ф. Р-1439. Оп. 4. Д. 231. Л. 1 об.
} 
тонн)» ${ }^{48}$. Далее оптимистично рапортовалось, что «фактически уже заложено 7 новых шахт, из которых 1 будет резервной на случай увеличения добычи. Также резервной является весь Сырский рудник с действующими шахтами и имеющими быть заложенными на нем новыми. Проходка новых шахт развивается успешно, и на 30 -е августа с. г. 6 новых шахт доведены до известняка, а 7-я будет доведена до известняка к 15 сентября с. г.» ${ }^{49}$. И уже совсем удивительную информацию местные власти сообщали о ходе подведения железнодорожных веток и электричества к строящимся или реконструирующимся рудникам. Так, в одном из отчетов, направленных руководством ЦЧО в Москву, сообщалось: «...Работы по железнодорожному строительству ведутся успешно, ... хотя в части фондов на стройматериалы, действительно, в 1-м полугодии из лесных материалов фактически не реализовано ничего. ... Состояние топографических работ вполне удовлетворительное... Временная подача энергии с расширяемой Липецкой электростанции обеспечена» (Выделено - Е.П.) ${ }^{50}$.

В ответ на оптимистичные региональные отчеты о благополучном выполнении и даже перевыполнении сроков плановых заданий, в Москве руководители соответствующих отделов ВСНХ выделяли все новые средства и оборудование для КМА. «Объем работ, обеспечивающих добычу 2 млн тонн с подробной спецификацией, определен в 1-й половине июня с. г., причем для проведения строительства в 1931 г. ассигновано 8760000 руб. На основе этого 1 июля с. г. ВСНХ СССР (дополнительно - Е.П.) выделены фонды на все основное оборудование... со сроком поставок, обеспечивающих своевременный пуск шахт в эксплуатацию. А 13-го августа с. г. ПредВСНХ СССР т. Кагановичем было предложено ВОМТу (Всесоюзный объединенный машиностроительный трест Е.П.) заключить договор с «Рудой» на изготовление упомянутого оборудования к 1-му кварталу 1932 г., т. е. в сроки, увязанные графиком окончания работ (по реконструкции Е.П.) Липецких рудников» 51 .

Сложные технологические решения в процессе реконструкции и расширения Липецких рудников потребовали применения не только отечественного, но и импортного оборудования. КИ сообщала в Москву, что с сентября 1931 г. «дальнейшая углубка шахт по известняку потребует применения взрывных работ и механического бурения на основе передвижных компрессоров с двигателями внутреннего сгорания». Из Москвы отвечали, что «заказ на указанные (импортные) компрессора оформлен и нашему представителю т. Кржижановскому, направленному в Берлин в комиссию тов. Пятакова, дано указание направить эти компрессора немедленно большой скоростью, почему получение компрессоров можно ожидать не позднее 1-го октября с. г.» ${ }^{52}$.

Несмотря на отчеты о благополучном выполнении плановых заданий, руководство ЦЧО все же осознавало не только сложность поставленной перед регионом задачи по разведкам, реконструкции и вводу в строй новых объектов КМА, но и тяжесть возможных последствий выявления истинного положения дел. В этой связи Обкомом ЦЧО в ВСНХ был отправлено предложение реорганизовать управление КМА, поддержанное правлением треста «Руда» в Харькове. Направленный в Москву исполняющий обязанности управляющего трестом «Руда» Горбачевский добился от руководства ВСНХ разрешения на структурные изменения в управлении КМА. Отныне геологоразведка и строительство отделялись от эксплуатации объектов. В обком и облисполком ЦЧО Горбачевский сообщал, что с 1сентября 1931 г. «для упорядочения управления нашим строительством «Рудой» (по согласованию с ВСНХ - Е.П.) принято решение отделить новое строительство от эксплуатации... Выделено самостоятельное управление по руководству строительством Ли-

\footnotetext{
${ }^{48}$ ГАВО. Ф. Р-1439. Оп. 4. Д. 229. Л. 33.

49 Там же. Л. 32, 33.

${ }^{50}$ Там же. Л. 33 об.

${ }^{51}$ ГАВО. Ф. Р-1439. Оп. 4. Д. 229. Л. 33-33 об.

52 Там же. Л. 33.
} 
пецких рудников «Липецкстрой», каковое укомплектовано необходимыми кадрами инженерперсонала, и со стороны «Руды» установлено особое наблюдение за этим строительством» 53 .

В целом из анализа приведенного материала следует, что создание материальнотехнической базы для изучения и освоения КМА, а также начало промышленной разведки и эксплуатации полезных ископаемых ЦЧО широким фронтом началось лишь в годы первой советской пятилетки (1928/29-1932/33 гг.). По масштабам процесс являлся грандиозным, и по результатам должен был коренным образом изменить исторически сложившийся хозяйственный механизм такого огромного традиционно аграрного региона Центральной России, каким являлась ЦЧО. Именно поэтому в ходе начала его реализации имели место значительные трудности и недочеты, вызванные как издержками административнокомандных методов руководства, сложившихся в СССР к началу 1930-х годов, так и завышением плановых заданий, вынужденно увязываемых руководством ЦЧО в общий контекст догоняющей, или «ускоренной модели» индустриализации, избранной политическими лидерами СССР.

Вместе с тем уже к середине 1930-х годов на этом направлении в Центральном Черноземье удалось добиться выдающихся результатов - была создана материальнотехническая база для дальнейшего ускоренного индустриального развития региона. Так, если в 1913 г. совокупная стоимость произведенной в регионе промышленной продукции (в сопоставимых ценах) оценивалась в 215 млн руб., то в 1928 г. - уже в 318 млн руб., а к 1932 г. в целом по ЦЧО она составила более 867 млн руб. То есть за годы первой пятилетки возросла в 2,7 раза. Впечатлял и рост капиталовложений в промышленный сектор экономики края: если в 1928 г. они составляли 17568 тыс. руб., то в 1932 г. - уже 155101 тыс. руб., то есть увеличились примерно в 8 раз. При этом бесспорный приоритет отдавался развитию тяжелых отраслей промышленности, где за указанный период вложения возросли с 5 млн 715 тыс. до 107 млн 689 тыс. руб., то есть в 19 раз [16, с. 11-12]. Наряду с широкой реконструкцией и коренным техническим перевооружением промышленности, за 4 года первой пятилетки в ЦЧО были введены в строй 20 новых крупных промышленных предприятий, а в 1932-1934 гг. достраивались и вводились в эксплуатацию еще 20 заводов, среди них Подгоренский цементный и Липецкий металлургический заводы, 4 шахты по добыче железной руды, Логовской комбинат дезентегрированного мела, Журавский охроплавильный и Букреевский фосфоритный заводы. В 1932 г. началось строительство крупнейшего в регионе Старооскольского металлургического комбината. Особо следует отметить, что, выполняя требование ЦК ВКП(б) «в кратчайший срок полностью освободиться от иностранной зависимости и производить все машины, оборудование и другие изделия на своих, отечественных заводах», к 1932 г. в ЦЧО было освоено производство дизелей, газогенераторов, целого ряда материалов «синтетической химии», высококачественных изделий из огнеупорных материалов и другой по тем временам высокотехнологичной промышленной продукции [Четыре года..., 1932, с. 13-14]. Уже к концу 1920-х гг. мелоизвестковое производство региона составляло $55 \%$ от всего производимого в СССР молотого мела и 21 \% - извести [Промышленность ЦЧО..., 1929, с. 19].

\section{Заключение}

Важный, по сути, окончательный вывод по дискуссии, продолжавшейся на протяжении 1920-х годов, о целесообразности индустриальной хозяйственной специализации ЦЧО в рамках процесса форсированной индустриализации страны сделала состоявшаяся в январе 1932 г. в Воронеже третья областная партийная конференция, которая особо отметила необходимость дальнейшего интенсивного разведывания «естественных богатств и недр... в направлении: а) использования мощной сырьевой железорудной базы КМА 
(КМА Липецк, Калач, Павловск), сырьевой базы по стройматериалам, фосфоритам, огнеупорам, цементу, сырьевой базы по синтетическим новым видам сырья; б) создания в ЦЧО мощной базы тяжелого и транспортного машиностроения, создания крупнорайонной базы заготовительных и передельных заводов, развития основной и синтетической химии, производства стройматериалов; в) строительства в ЦЧО крупной энергетической базы...; г) организации в ЦЧО громадного узла транзитных магистралей...» [Шевяков, Маньковский, 1962, с. 43-44]. Конференция отметила также необходимость в ближайшей перспективе второй пятилетки «объединения металлургического производства и руд КМА в один комбинат южной металлоугольной базы при создании в ЦЧО мощного металлургического производства с коксовыми установками, снабжаемыми углем из Донбасса и Подмосковного бассейна, и вывоза руды на металлургические заводы Донбасса. Комбинирование металлургических заводов ЦЧО с машиностроительными заводами ЦЧО и Центра на началах поставки ...литейных частей и деталей передельного чугуна, стали, тяжелого машиностроения... При этом само индустриальное развитие ЦЧО должно явиться огромнейшим фактором дальнейшего развития всей европейской части Союза, как южной, так и центральной» [Шевяков, Маньковский, 1962, с. 44-45].

Преодолевая трудности, существенные успехи были достигнуты и в социальной сфере Черноземного Центра РСФСР, прежде всего в оплате «промышленного труда». Так, например, с 1928/29 по 1932/33 гг. среднемесячная зарплата рабочих региона по металлургической промышленности возросла с 61 руб. 48 коп. до 121 руб. 26 коп. (на 97,2 \%); по машиностроению - с 62 руб. 76 коп. до 88 руб. 33 коп. (на 40,7 \%); по мелоизвестковому производству - с 36 руб. 10 коп. до 63 руб. 36 коп. (на 75,5 \%); по кирпичному производству - с 42 руб. 31 коп. до 52 руб. 43 коп. (на 23,9 \%). Значительно улучшилось снабжение рабочих товарами первой необходимости и система общественного питания на промышленных предприятиях ЦЧО [Шевяков, Маньковский, 1962, с. 18].

Подводя итог вышесказанному, следует констатировать, что, несмотря на целый ряд проблем, существенно осложнявших разведку и освоение природных богатств ЦЧО, прежде всего КМА, в ходе индустриальной модернизации края к середине 1930-х годов была заложена прочная основа для трансформации Центрального Черноземья из депрессивно-аграрного в динамично развивающийся индустриально-аграрный регион РСФСР.

\section{Список литературы}

1. Антропов П.Я. 1958. Курская магнитная аномалия. Москва, Знание, 24.

2. Бусыгин И.А. 1969. Путь к кладу земли. Москва, «Недра», 104.

3. Быковская Г.А. 2000. Научно-техническая политика российского государства: опыт исторической реконструкции. Воронеж, Воронежская технол. акад., 300.

4. Железорудная база России. Под ред. В.П. Орлова. 1998. Москва, ЗАО «Геоинформарк», 842.

5. КМА набирает высоту: сб. статей, очерков об освоении КМА. Сост. К.М. Новоспасский, М.П. Козлов. 1974. Воронеж., Центр.-Черноземное кн. изд-во, 142.

6. Кривошеев Т.И. 1965. Борьба КПСС за создание нового железорудного бассейна СССР - Курской магнитной аномалии (1918-1961 гг.): дис. канд. ист. наук. Харьков, 157.

7. Крупенков Н.Ф. 1973. Сокровища третьего магнитного полюса. Москва, Политиздат, 127.

8. Курская магнитная аномалия: история открытия, исследований и промышленного освоения железорудных месторождений. Сб. док-ов и мат-ов: 1742-1926. Т. 1. Белгород, 1961; 1926-1962. Т. 2. Белгород, 1962.

9. Мальцев И.И. 1968. Развитие черной металлургии Черноземного Центра (1917-1967 гг.): дис. канд. ист. наук. Москва, 210.

10. Пешехонова О.В. 2011. Освоение Курской магнитной аномалии за 1931-1945 гг. Ученые записки: электронный научный журнал Курского госуд. ун-та. Курск, Том 2.3 (19): 15-27.

11. Прокофьева Е.Ю. 2015. Промышленность по добыче и обработке полезных ископаемых на территории Центрального Черноземья: трудности и перспективы развития в 1920-е 
годы. Часть 1. Исторические, философские, политические и юридические науки, культурология и искусствоведение. Вопросы теории и практики. Тамбов, 8 (58): 162-167.

12. Прокофьева Е.Ю. 2016. Промышленность по добыче полезных ископаемых в Центрально-Черноземной области: к вопросу о трудностях и перспективах развития в конце 1920-х - начале 1930-х гг. Часть 2. Исторические, философские, политические и юридические науки, культурология и искусствоведение. Вопросы теории и практики. Тамбов, 11 (73): 150-156.

13. Промышленность ЦЧО и ее перспективы. 1929. Воронеж, [тип. ОкрСНХ], 133.

14. Слободенюк Н.В. 2009. Формирование и развитие горно-металлургического комплекса в районе Курской магнитной аномалии во второй половине XX - начале XXI веков (на материалах Белгородской области): дис. канд. ист. наук. Курск, 226.

15. Толмачева Е.А. 2011. Становление и развитие горно-геологической службы России и СССР: 1882-1928 гг. (на примере Курской губернии): дис. канд. ист. наук. Курск, 204.

16. Четыре года социалистической реконструкции ЦЧО. 1932. Воронеж, «Коммуна», 136.

17. Шевяков Л.Д., Маньковский Г.И. 1962. Курская магнитная аномалия. Москва, Изд-во AH CCCP, 99.

18. Юров А.Ф. 1967. Из истории освоения богатств Курской магнитной аномалии (1918-1966 гг.): дис. канд. ист. наук. Москва, 206.

\section{References}

1. Antropov P.Ya. 1958. Kurskaya magnitnaya anomaliya [Kursk Magnetic Anomaly]. Moscow, Znanie, 24 (in Russian).

2. Busygin I.A. 1969. Put' k kladu zemli [The road to the earth treasure]. Moscow, «Nedra», 104 (in Russian).

3. Bykovskaya G.A. 2000. Nauchno-tekhnicheskaya politika rossiyskogo gosudarstva: opyt istoricheskoy rekonstruktsii [Scientific and technical politics of Russian Federation - experience of historical reconstruction]. Voronezh, Voronezhskaya tekhnol. akad., 300 (in Russian).

4. Zhelezorudnaya baza Rossii [Iron ore base of Russia]. Pod red. V.P. Orlova. 1998. Moscow, ZAO «Geoinformark», 842 (in Russian).

5. KMA nabiraet vysotu: sb. statey, ocherkov ob osvoenii KMA [KMA is growing up: collection of articlesaб and essay about KMA development]. Sost. K.M. Novospasskiy, M.P. Kozlov. 1974. Voronezh., Tsentr.-Chernozemnoe kn. izd-vo, 142 (in Russian).

6. Krivosheev T.I. 1965. Bor'ba KPSS za sozdanie novogo zhelezorudnogo basseyna SSSR Kurskoy magnitnoy anomalii (1918-1961 gg.) [Soviet Union Struggle to new iron ore basin creation Kursk Magnetic Anomaly (1918-1961)]: dis. kand. ist. nauk. Khar'kov, 157.

7. Krupenkov N.F. 1973. Sokrovishcha tret'ego magnitnogo polyusa [Treasure of the 3-rd magnetic pole]. Moscow, Politizdat, 127 (in Russian).

8. Kurskaya magnitnaya anomaliya: istoriya otkrytiya, issledovaniy i promyshlennogo osvoeniya zhelezorudnykh mestorozhdeniy [Kursk Magnetic Anomaly: the history of research and industry iron ore development]. Sb. dok-ov i mat-ov [Collection of documents and materials]: 1742-1926. T. 1. Belgorod, 1961; 1926-1962. T. 2. Belgorod, 1962 (in Russian).

9. Mal'tsev I.I. 1968. Razvitie chernoy metallurgii Chernozemnogo Tsentra (1917-1967 gg.) [Ferrous metallurgy development of the Central Black Earth (1917-1966)]: dis. kand. ist. nauk. Moscow, 210 (in Russian).

10. Peshekhonova O.V. 2011. Osvoenie Kurskoy magnitnoy Anomalii za 1931-1945 gg. Uchenye zapiski: elektronnyy nauchnyy zhurnal Kurskogo gosud. un-ta [Kursk Magnetic Anomaly development during 1931-1945]. Kursk, Tom 2.3 (19): 15-27 (in Russian).

11. Prokof'eva E.Yu. 2015. Promyshlennost' po dobyche i obrabotke poleznykh iskopaemykh na territorii Tsentral'nogo Chernozem'ya: trudnosti i perspektivy razvitiya v 1920-e gody. Chast' 1 [Industry of mineral resources on the territory of the Central Black Earth - difficulties and prospects of development in 1920-s]. Istoricheskie, filosofskie, politicheskie i yuridicheskie nauki, kul'turologiya i iskusstvovedenie. Voprosy teorii i praktiki. Tambov, 8 (58): 162-167 (in Russian).

12. Prokof'eva E.Yu. 2016. Promyshlennost' po dobyche poleznykh iskopaemykh v Tsentral'noChernozemnoy Oblasti: k voprosu o trudnostyakh i perspektivakh razvitiya v kontse 1920-kh - nachale 1930-kh gg. Chast' 2 [Mineral resources industry of the Central Black Earth: question s of difficulties and prospects of development in 1920-1930-s]. Istoricheskie, filosofskie, politicheskie i yuridicheskie nauki, kul'turologiya i iskusstvovedenie. Voprosy teorii i praktiki. Tambov, 11 (73): 150-156 (in Russian). 
13. Promyshlennost' Ts.Ch.O. i ee perspektivy [The Central Black Earth industry and it's prospects]. 1929. Voronezh, [tip. OkrSNKh], 133 (in Russian).

14. Slobodenyuk N.V. 2009. Formirovanie i razvitie gorno-metallurgicheskogo kompleksa v rayone Kurskoy magnitnoy anomalii vo vtoroy polovine XX - nachale XXI vekov (na materialakh Belgorodskoy oblasti) [Mining and metallurgical complex development of Kursk Magnetic Anomaly during XX-XI century (based on Belgorod region)]: dis. kand. ist. nauk. Kursk, 226 (in Russian).

15. Tolmacheva E.A. 2011. Stanovlenie i razvitie gorno-geologicheskoy sluzhby Rossii i SSSR: 1882-1928 gg. (na primere Kurskoy gubernii) [Mining and geological survey development of Russia and USSR: 1882-1928 (based on Kursk region)]: dis. kand. ist. nauk. Kursk, 204 (in Russian).

16. Chetyre goda sotsialisticheskoy rekonstruktsii Ts.Ch.O. [4 years of socialist reconstruction of the Central Black Earth Region]. 1932. Voronezh, «Kommuna», 136 (in Russian).

17. Shevyakov L.D., Man'kovskiy G.I. 1962. Kurskaya magnitnaya anomaliya [Kursk Magnetic Anomaly]. Moscow, Izd-vo AN SSSR, 99 (in Russian).

18. Yurov A.F. 1967. Iz istorii osvoeniya bogatstv Kurskoy magnitnoy anomalii (1918-1966 gg.) [From history of prosperity development of Kursk Magnetic Anomaly (1918-1966)]: dis. kand. ist. nauk. Moscow, 206 (in Russian).

\section{ИНФОРМАЦИЯ ОБ АВТОРЕ}

Прокофьева Елена Юрьевна, кандидат исторических наук, доцент кафедры российской истории и документоведения Белгородского государственного национального исследовательского университета, г. Белгород, Россия

\section{INFORMATION ABOUT THE AUTHOR}

Elena Yu. Prokofieva, candidate of Historical Sciences, Associate Professor of the Department of Russian History and Documentation, Belgorod State National Research University, Belgorod, Russia 